\title{
FROM NEUROLOGICAL PATIENT TO PSYCHIATRIC PATIENT
}

A. Duque ${ }^{1}$, C. García Montero', R. Duque Domínguez², J. Ruiz Navarro', M. Palomo Monge ${ }^{3}$, N. Echeverría Hernández', F. de la Torre Brasas ${ }^{1}$ M. Martín Román ${ }^{1}$, M. Mejía Quiterio ${ }^{1}$, C. Fernández Muñiz1, E. Pérez Arévalo ${ }^{1}$, M.N. Vaquero López', J. Bango Suárez'

${ }^{1}$ Complejo Asistencial de Ávila, Servicio de Psiquiatría, Ávila, Spain. ${ }^{2}$ Hospital Universitario de Fuenlabrada, Servicio de Psiquiatría, Madrid, Spain ${ }^{3}$ Hospital Nuestra Señora del Prado, Servicio de Psiquiatría, Talavera de la Reina, Spain

\section{OBJ ECTI VES}

Patients with functional neurologic disorders present to clinicians with a variety of symptomatic manifestations, with various levels of severity, chronicity, and comorbidity, as well as with various degrees of past adversity, intrinsic resilience, and available external support. Clearly, treatment must be individualized. There are patients who have been severely or chronically impaired, especially if adequate prior outpatient treatments have failed. For patients with severe levels of disability, who could be managed in a multimodal day-treatment program, that approach also warrants further consideration.

\section{BACKGROUND AND AIMS}

We present the clinical case of a patient under treatment by multiple specialists (neurology and digestive, among others) who is finally diagnosed with a conversion disorder.

\section{MATERI ALS AND METHODS}

Description of a clinical case and review of scientific literature.

\section{RESULTS}

40-year-old woman, who is admitted to a psychiatric day hospital with the following objectives: - Realization of psychometrics. - Try to normalize the diction.

\section{PERSONAL HISTORY:}

Migraines (vascular-tension headaches) Irritable bowel Pseudoconvulsive crisis in follow-up by Neurology. In follow-up by psychiatry for 20 years. Diagnosed of: histrionic personality disorders, anxiety crisis and mixed adaptive disorder.

\section{CURRENT ILLNESS:}

The patient and her family report that for a year and in the same way that has happened on other occasions, she presents difficulties in verbal expression (omits articles and pronouns, changes tenses, reverses the order between the adjective and the name, etc.) On all other occasions, this clinic had yielded spontaneously and in a short space of time. They also indicate that when you get nervous, you have "seizures." It is being valued by neurology for years. His parents accompany him to all the sites "in case of crisis." As main problems, she talks about not being able to live with her boyfriend, because he can't find a job and she is sick.

\section{PSYCHOLOGICAL EVALUATION}

SCL-90-R: indicates a tendency to exaggerate symptoms. The "peaks" of the profile are the Scales of obsessions, phobias, interpersonal sensitivity and paranoia. The patient's behavior shows no signs of social anxiety or suspicion or self referentiality. Call the attention to the score on the scale of hostility, which is strikingly low, denying feeling angry or irritation or having aggressive impulses in any situation.

SIMS: the total score -39- suggests that the patient has frequently answered items related to symptoms atypical in patients with genuine psychopathological or neurocognitive disorders.

The most accentuated personality traits seem to be those of the histrionic and dependent type.

\section{EVOLUTION IN THE UNIT:}

The patient adapts correctly to the rules of the unit. From the beginning shows surprisingly talkative, without evidencing anxiety or inhibition in relation to his difficulties of verbal expression (omits particles, changes verb tenses, reverses the order between the adjective and the noun, etc., with a language similar to that observed in the "foreign accent syndrome"). She says that suffers "pseudocrisis" in which she loses consciousness and that, about ten years ago, began to present episodes in the that has shown cognitive difficultiesproblems to manage money, difficulties in verbal expression or in the reading, etc.-, that other times they have remitted, but that in this occasion they seem not to improve. Live with her parents. Although she has been a boyfriend for 18 years. Refers lack of acceptance by the family of her boyfriend. Despite this, she says that she does not hold a grudge against them. A month after entering, the progressive appearance of new symptoms is observed periodically (from organic and psychological characteristics). Adds alleged auditory hallucinations and visions of her grandmother deceased. During the first months of admission, the patient presents several episodes of convulsive pseudocrisis at home, some of which require treatment in the service of emergencies.We decided that the patient go to a type of Individualized workshops with the team's Occupational Therapist, to learn money management and rehabilitate. She speaks, resulting positive for the patient. Regarding the psychopharmacological treatment, the patient is included in the therapeutic adherence group for readjust the medication and that it is she who takes charge of the preparation and takes her treatment (until now he delegated to his mother). We agreed the change of valproate by pregabalin, to check the evolution of its seudoneurological picture and at the same time minimize side effects that valproate is producing. In this context, pseudo-crises begin to be reduced, disappear.

CLINICAL JUDGMENT:

- 300.11 (F44.7) Conversion disorder with mixed symptoms (seizures or attacks and speech symptoms).

-Character traits of histrionic and dependent type. Persistent epsyiod without psychological stress factor.

TREATMENT AT DISCHARGE:

Desvenlafaxine $50 \mathrm{mg}$, Diazepam $5 \mathrm{mg}$ and Pregabaline $75 \mathrm{mg}$.

\section{CONCLUSI ONS}

The management of patients with functional neurological disorders is a challenge for specialists. Psychological treatment begins at the time of the first diagnosis, when the patient and his or her family members or caregivers must be explained in a careful manner about the nature of their illness.

\section{BI BLI OGRAPHI C REFERENCES}

1. Kaplan HI, Sadock BJ. Sinopsis de Psiquiatría. 10a ed. Barcelona: Wolters Kluwer; 2009.

2. Vallejo Ruiloba J., Leal Cercós C. Tratado de Psiquiatría. Madrid: Marbán; 2012.

3. Palomo T., Jiménez-Arriero M.A. Manual de Psiquiatría. Madrid: Grupo ENE Publicidad, S.A

4. APA, DSM-5 Manual diagnóstico y estadístico de los trastornos mentales. 5aed. Madrid: Panamericana; 2014.

5. CIE 10. Décima revisión de la clasificación internacional de las enfermedades. Trastornos mentales y del comportamiento. Publicado por la OMS en Ed Meditar (Madrid). Ginebra 1992. 